\title{
Hepatic encephalopathy in adult dog secondary to cirrhosis due to congenital biliary agenesis: a case report
}

\author{
Encefalopatia hepática em cão adulto secundária a cirrose \\ causada por agenesia biliar congênita: relato de caso
}

\author{
Fernanda Bueno Oliveira ${ }^{1}$ (D); Thanielle Novaes Fontes ${ }^{3}$ (1); Marilaine Carlos Sousa ${ }^{2}$ (1); \\ Ana Caroline da Silva Néto Souza ${ }^{3}$ (1); Tiago da Cunha Peixoto ${ }^{4}$ (1); Paula Velozo Leal ${ }^{4^{*}}$ (1)
}

\begin{abstract}
Gallbladder agenesis is a congenital malformation that is considered extremely rare in dogs. The disease can course asymptomatically or with clinical signs, usually non-specific and including vomiting, anorexia, diarrhea, ascites, and lethargy. The objective of this report was to describe the clinical and anatomopathological aspects of a dog with hepatic encephalopathy secondary to gallbladder agenesis. This condition can be diagnosed during surgery or imaging examinations; however, it is often an incidental finding. In the biochemical examinations, a decrease in alanine aminotransferase and an increase in alkaline phosphatase and hypoalbuminemia were observed. During the necropsy, hepatomegaly was observed with absence of the gallbladder, congestion, cerebral edema, lipiduria, and pulmonary edema. Microscopically, there was intense fibrosis and inflammation in the liver due to chronic cholangiohepatitis (cirrhosis of the liver). The consequence of this lesion secondary to gallbladder agenesis was hepatic encephalopathy. Chronic liver failure exposes the cerebral cortex to toxins that are not metabolized by the liver, such as ammonia, mercaptans, short-chain fatty acids, scatols, indols, and aromatic amino acids. These toxins cause reversible damage to the brain, which results in neurological disorders. In this report, the dog had no clinical neurological signs, and the diagnosis of this condition was observed histologically. Dogs with gallbladder agenesis usually have clinical and pathological findings of hepatobiliary lesions such as cholestasis, cholangiohepatitis, and, in severe cases, hepatic encephalopathy, which are necessary to differentiate from other diseases that affect the hepatobiliary system, such as cholelithiasis, neoplasms, and chronic hepatitis.
\end{abstract}

KEYWORDS: canine; cerebral spongiosis; liver cirrhosis; congenital malformation.

RESUMO: A agenesia de vesícula biliar é uma má formação congênita, considerada extremamente rara em cães. A doença pode cursar de forma assintomática ou com sinais clínicos, geralmente, inespecíficos que incluem vômitos, anorexia, diarreia, ascite e letargia. O objetivo deste relato foi descrever os aspectos clínicos e anatomopatológicos de um cão com encefalopatia hepática secundária a agenesia da vesícula biliar, esta condição pode ser diagnosticada durante uma cirurgia ou exames de imagem, entretanto frequentemente é um achado incidental. Como resultados, nos exames bioquímicos observou-se a diminuição da alanina aminotransferase, aumento da fosfatase alcalina e hipoalbuminemia. Durante a necropsia foi observado hepatomegalia com ausência da vesícula biliar, congestão e edema cerebral, lipidúria e edema pulmonar. Microscopicamente, no fígado havia intensa fibrose e inflamação pela colangiohepatite crônica (cirrose hepática). A consequência desta lesão secundária a agenesia da vesícula biliar, foi a encefalopatia hepática. A insuficiência hepática crônica expõe o córtex cerebral às toxinas não metabolizadas pelo fígado, tais como a amônia, mercaptanos, ácidos graxos de cadeia curta, escatóis, indóis e aminoácidos aromáticos. Essas toxinas causam danos reversíveis ao encéfalo, o que resulta em distúrbios neurológicos. No presente caso, o cão não apresentou sinais clínicos neurológicos e o diagnóstico desta condição foi observado histologicamente. Cães com agenesia de vesícula biliar, geralmente exibem achados clínicos e patológicos de lesóes hepatobiliares, como colestase, conlangiohepatite e, em casos graves, encefalopatia hepática, sendo necessário diferenciar de outras doenças que acometem o sistema hepatobiliar, como colelitíase, neoplasias e hepatites crônicas.

PALAVRAS CHAVE: Canino, espongiose cerebral, cirrose hepática, malformação congênita. 


\section{INTRODUCTION}

Gallbladder agenesis is considered a rare anomaly that often occurs asymptomatically, and its diagnosis occurs incidentally during surgical procedures or necropsy. Some patients may develop gallstones in the bile duct, which obstructs the bile tract; therefore, it is essential to perform a surgical intervention to avoid possible complications (CARVALHO et al., 2017).

Although the factors involved in the pathogenesis of the disease development are not well understood, it is considered an embryological disorder that occurs at the time of organogenesis, possibly hereditary. The gallbladder, bile ducts, and liver begin to develop with the growth of the endodermic tube. During the growth of the liver, a second caudal growth of the original hepatic diverticulum, the cystic bud, occurs, giving rise to the gallbladder and cystic duct (BEDI et al., 2013). Failure during cystic duct formation may result in congenital gallbladder absence (TURKEL; SWANSON; CHANDRASOMA, 1983; CARVALHO et al., 2017).

Gallbladder agenesis in humans can be divided into asymptomatic, symptomatic, or that associated with other congenital anomalies. Symptoms include pain in the upper right quadrant, jaundice, and intolerance to fatty foods. The differential diagnosis should be performed with choledocholithiasis and biliary dyskinesia (CARVALHO et al., 2017). Clinical and prognostic information on gallbladder agenesis in dogs is poor; however, an increase in hepatic enzyme activity, such as alanine aminotransferase (ALT), has already been reported in dogs with this malformation (AUSTIN; TILLSON; KUHNT, 2006). This case report describes this condition in a dog, poodle breed, with non-specific clinical signs, diagnosed through anatomopathological findings.

\section{CASE REPORT}

The use of data from the Laboratory of Veterinary Pathology (LPV) was approved by the Ethics Committee on Animal Use (CEUA) of the School of Veterinary Medicine and Zootechny of the Federal University of Bahia (UFBA) with protocol number $075 / 20$.

A 9-year-old dog of the poodle breed, weighing $2.5 \mathrm{~kg}$, was admitted to the emergency department of the UFBA Veterinary Hospital (HOSPMEV), as symptomatology presented paralysis in all limbs, pain, and apathy. The tutor reported that the animal was not moving, was anorexic, and had adipsia since the previous week. The presence of ectoparasites (ticks) was also reported, and that the animal was semidomesticated, besides being not properly vaccinated. During the physical examination, pain was observed in the thoracolumbar and cervical spine region, along with proprioception deficit and increased reflexes, suggesting injury to the upper motor neurons.

Complementary tests (hemogram [tubes with EDTA $\mathrm{K} 2$ ], biochemical tests [tube with clot activator], and thoracolumbar and cervical radiography) were performed to confirm the initial suspicion of discopathy, hemoparasitosis, or neoplasia. After the general and specific clinical examination, the animal was stabilized with Ringer's lactate fluid therapy with hydrocortisone $(10 \mathrm{mg} / \mathrm{kg})$, vitamin C, B complex, and tramadol. Later, in the biochemical examination, a decrease in ALT concentrations (15 IU/L, reference range 21-102 IU/L) and a sharp increase in alkaline phosphatase concentrations (485 IU/L, reference range 20-156 IU/L) and hypoalbuminemia $(1.8 \mathrm{~g} / \mathrm{dL}$, reference range $2.6-3.3 \mathrm{~g} /$ $\mathrm{dL}$ ) were demonstrated. In the rest of the biochemical tests, the dosages of urea, creatinine, and globulins were within the physiological standards for the species. The CBC showed normochromic normocytic mild anemia without regeneration criteria, thrombocytosis, and leukocytosis, and neutrophilia with left shift. Cervical and thoracolumbar spine radiographic exams showed findings that could be related to intervertebral disc/spondylarthrosis disease.

The following day, the animal was sent to the hospital and stayed for at least $72 \mathrm{~h}$. Ringer's lactate fluid therapy was administered with vitamin $\mathrm{C}$, B complex, hydrocortisone, morphine, and medications prescribed; however, the dosages and frequency were lacking in the history and clinical records. The initial treatment was based on pain control and patient stabilization for further detailed investigation. The animal was discharged from the hospital; however, after 5 days, it died and was referred to the LPV-UFBA for diagnostic elucidation.

At necropsy, hepatomegaly was observed, besides a bright capsular surface with friable consistency and absence of the gallbladder (figure 1A). There was no history of cholecystectomy, and there were no macroscopic alterations compatible with this procedure. The abdominal liquid was scarce, clear, and translucent, but insufficient for analysis. The gastrointestinal tract was observed in the stomach mucous content with bile pigment (figure 1B). In the ileum, the serosa was slightly hyperemic and, in the rectum, steatorrhea was observed. Additionally, pulmonary edema, nephrosis, hydronephrosis, and urinary bladder were filled with fatty urine (lipiduria) (figure 1C). In the central nervous system (CNS), the encephalon presented diffusely congested and with reduced brain circumvolutions (edema) (figure 1D). During the necropsy, tissue fragments were collected, and the material was fixed in $10 \%$ formalin and routinely processed to make histological slides stained with hematoxylin and eosin.

Histopathological findings revealed the disorganization of the cordonal organization, multiple regeneration nodules, increased intrahepatocyte bilirubin, steatosis, proliferation of bile ducts, and inflammation in the liver, characterizing a chronic condition of cholangiohepatitis (figure 2). In encephalus, the presence of cortical laminar necrosis was characterized by intense vacuolization and vascular hyperplasia, more evident in the transition from white to gray substance, conferring to the cortex status spongiosus (figure 3). 

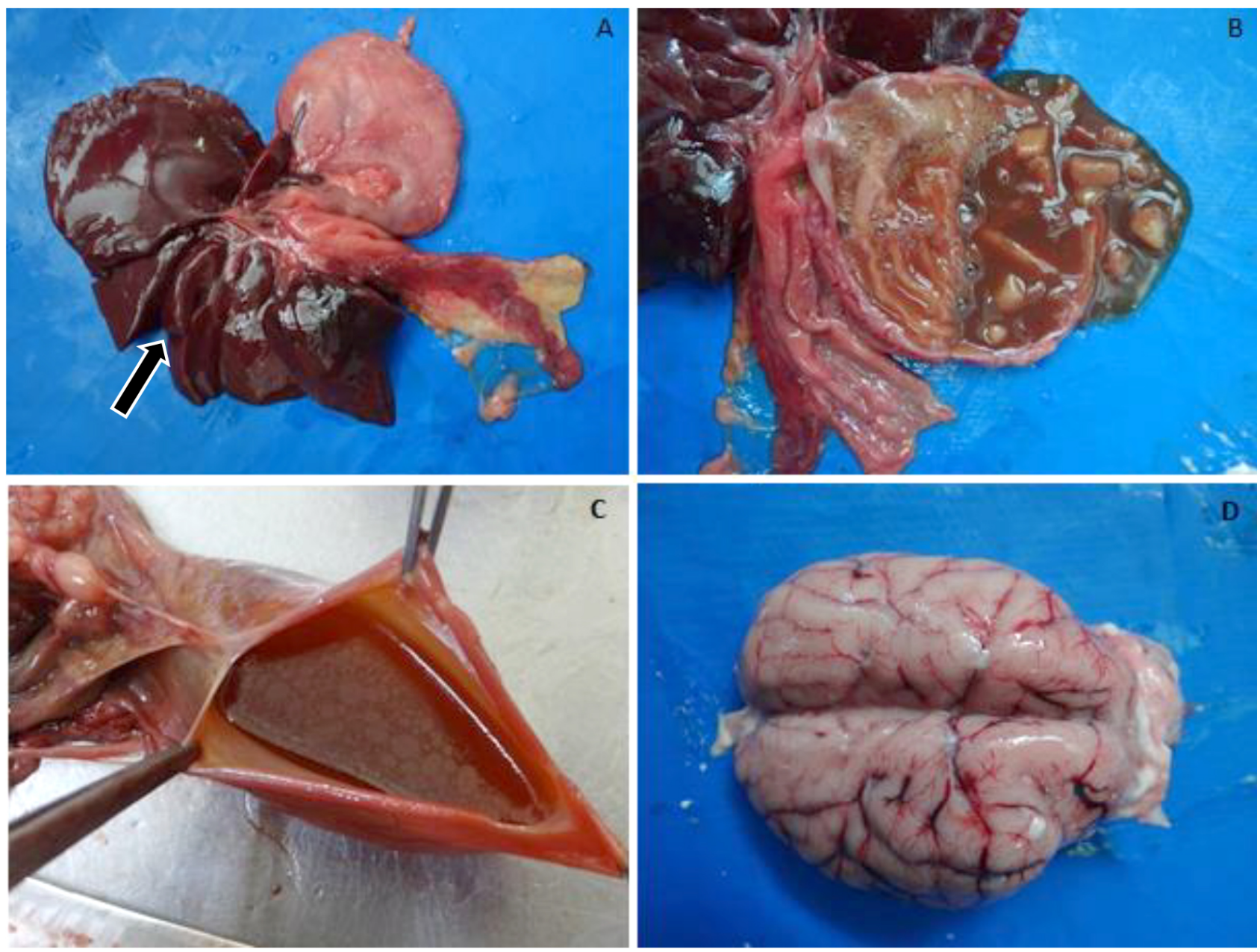

Figure 1. Canine necropsy findings. (A) Hepatomegaly is associated with gallbladder agenesis in a poodle dog; the arrow shows the space between the square and the right lobe. (B) Stomach with mucous content and bile pigment. (C) Greasy appearance content in the urinary vesicle. (D) Accentuated reduction of circumvolution associated with CNS congestion.

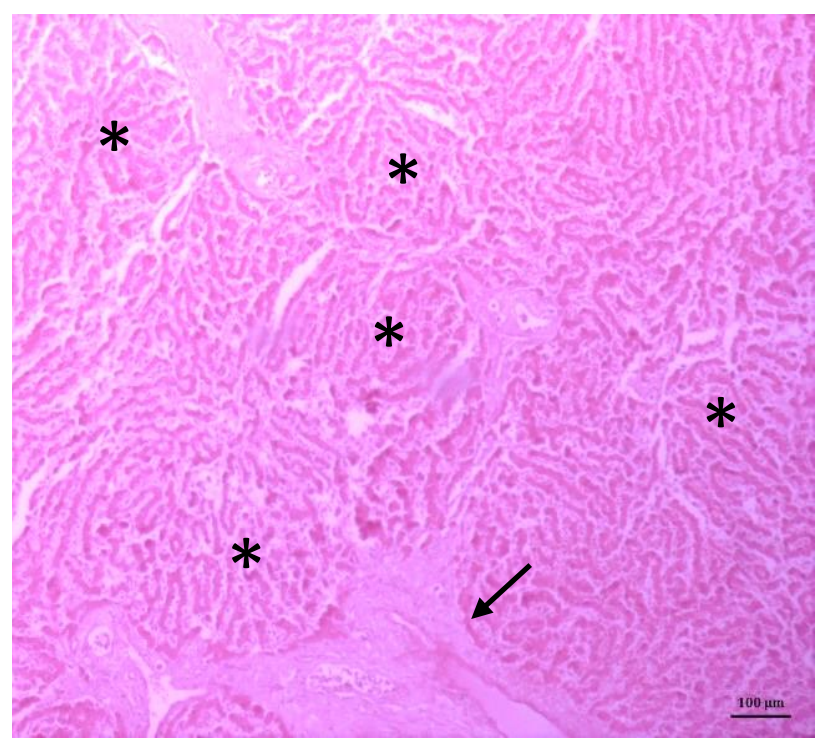

Figure 2. Canine. Liver. Histological sections of the liver presenting accentuated portal fibrosis (arrow) and multiple regeneration nodules $\left({ }^{*}\right)$. H\&E. Obj.1OX.

\section{DISCUSSION}

Diagnosis of hepatic encephalopathy was due to the association of anatomopathological findings related to chronic changes because of congenital biliary agenesis. Gallbladder agenesis is a rare condition in humans and extremely rare in dogs (CARVALHO et al., 2017). It was observed in a study by SATO et al. (2016), which found that the presentation of gallbladder agenesis affects most small breeds; some dogs showed increased activity of liver enzymes and histological changes in the liver portal and bile system, and $12 \%$ of them showed progressive liver failure.

Bile is formed in the liver and drained from the intrahepatic lobar ducts into the common and cystic bile duct and then stored and concentrated in the gallbladder. Bile secretion by the liver provides a source of bile acids for fat digestion (GOFF, 2015). The absence of postprandial bile due to agenesis can result in poor digestion when the diet fat exceeds a certain limit (LIPTAK et al., 2000). The presence of steatorrhea reported in this paper is attributed because of decreased 


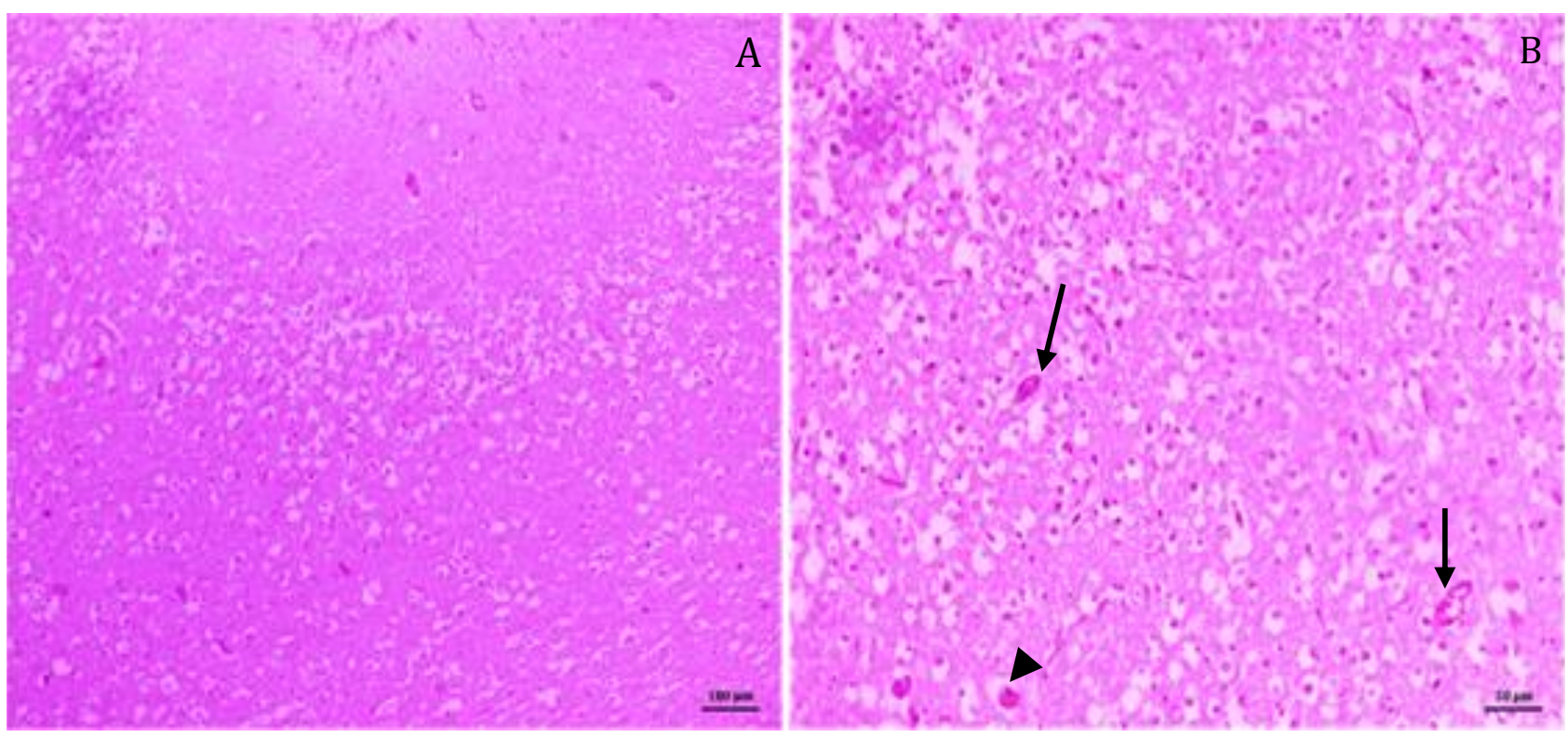

Figure 3. Canine. Brain, myelin sheaths vacuolization (status spongiosus). This lesion was found mainly in the brainstem and at the junction of the brain gray substance and subcortical white substance of the frontal, parietal, and occipital telencephalon and ganglia of the base. A, Laminar necrosis with areas of H\&E; vacuolization is observed in Obj. 10x. B, Vasogenic edema in greater increase, evidencing endothelial hyperplasia (arrow) and red neurons. H\&E Obj. 40x (b).

fat absorption, and the patient may evolve with malnutrition and signs and symptoms due to deficiency of fat-soluble vitamins (SINHA; DAVENPORT, 2008).

Dogs may present as asymptomatic or symptomatic, and many times, as in this report and previous reports, the clinical signs are non-specific, such as vomiting, anorexia, and mild gastrointestinal signs, and are later associated with increased concentrations of hepatic enzymes in the blood (AUSTIN; TILLSON; KUHNT, 2006; SATO et al., 2016; KELLY; MORENO-AGUADO; LAMB, 2019). The causes of clinical signs that may or may not be present in this syndrome and high concentrations of enzymes in dogs have not yet been well elucidated. However, secondary cholangiohepatitis or cholestasis has been suggested due to the reflux of intestinal content through the common bile duct (LIPTAK et al., 2000; SINHA; DAVENPORT, 2008). The increase in alkaline phosphatase (AP) reported in this paper is justified by the proliferation of epithelial cells in the bile duct due to bile stasis associated with cholangiohepatitis, in agreement with previous reports (LIPTAK et al., 2000).

The hematological findings may be associated with anemia of the chronic disease or inflammation; however, this inference would only be confirmed with complementary examinations, which could not be conducted in this case due to the clinical course (NAIGAMWALLA; WEBB; GIGER, 2012).

Macroscopically, lobular and hepatic parenchyma alterations can be observed, such as hypoplasia of the hepatic lobes, if there is a more complex failure in embryological development (BEDI et al., 2013). Genetic factors have already been related to the etiology of the disease in humans, which can be related to dogs that suffer from this disease because most are purebred. In this report, the dog was of the poodle breed, which is in line with previous studies that showed a correlation between purebred dogs and gallbladder agenesis (LIPTAK, et al., 2000; SATO et al., 2016; CARVALHO et al., 2017; KELLY; MORENO-AGUADO; LAMB, 2019).

SATO et al. (2016) suggested that there are relationships between congenital anomalies that can be identified histologically, such as malformations, in the ductal plate and hypoplasia of the portal vein. Portal fibrosis with bile duct hyperplasia, vascular proliferation, lymphoplasmacytic inflammatory infiltrate in the hepatic parenchyma, and bile duct dilation, which is clinically suspected, can also be found. In this report, histopathology of the liver showed a chronic inflammatory condition and proliferation of the bile ducts; thus, cholangiohepatitis secondary to gallbladder agenesis was considered (SATO et al., 2016; KELLY; MORENO-AGUADO; LAMB, 2019).

The dog in this report showed chronic liver failure, clinically manifested by hypoalbuminemia, which occurs due to decreased hepatic albumin synthesis. It also showed increased Palkaline phosphatase, related to cholangiopathy, and decreased ALT due to hepatocyte necrosis, which synthesizes the enzyme in a smaller amount by cellular damage (JOHNSTON, 1999; NELSON; COUTO, 2015; SCHMILOVITZ-WEISS; GINGOLD-BELFER; GROSSMAN, 2019). Hypoalbuminemia is directly associated with decreased oncotic pressure; therefore, the presence of cavitary fluids can be observed in clinical pictures of hepatobiliary diseases (NELSON \& COUTO, 2015). However, it was not a constant finding described in previous reports (SATO et al., 2016). In agreement, the dog in this case report showed hypoalbuminemia without cavity edema. 
Severe hepatobiliary diseases can result in liver failure due to the functional disability of the liver, which in turn leads to several complications, including hepatic encephalopathy. Thus, toxins that are not metabolized by the liver, such as ammonia, mercaptans, short-chain fatty acids, scatols, indols, and aromatic amino acids, are exposed in the cerebral cortex that causes damage to the tissue, which is considered a reversible abnormality (NELSON; COUTO, 2015). Such changes were observed in the described patient.

The animal showed, parallel to the findings related to the hepatobiliary system, spinal disc disease and spondyloarthrosis, caused by protrusion or extrusion of the intervertebral disc material into the spinal canal, which may cause spinal compression (CHERRONE et al., 2004). The cause of the disease is related to degeneration of the intervertebral disc. This variable is between fibroid and chondroid (RAMALHO et al., 2015). In this case report, the dog showed pain at neurological physical examination, increased reflexes, and proprioception deficit, which matche the symptoms of this pathology reported in previous studies (RAMALHO et al., 2015). It can be said that liver failure was part of the diagnostic algorithm, which initially prioritized the stabilization of the patient for subsequent clinical management, but there was no time for in vivo investigation, and the appropriate diagnostic conclusion was made only after necropsy.

The diagnosis of gallbladder agenesis in dogs is mostly performed during some surgical intervention or necroscopic examination and is reported as an incidental finding; however, with advances in imaging resources, cases such as gallbladder agenesis can be diagnosed without necessarily requiring intervention. Laparotomy allows a better exploration of the abdominal cavity, but invasive procedures should be avoided, and the investigation should continue with other diagnostic modalities (CARVALHO et al., 2017). In abdominal ultrasound, although it has a high sensitivity to gallbladder-related syndromes, some factors can interfere with outcomes, such as operator ability, and variables such as intestinal gas and atrophic gallbladder (BEDI et al., 2013). In this case report, it must be considered that the clinic of accentuated pain, associated with the diagnosis of the vertebral lesion, has made the prioritization of pain control and clinical stabilization notorious; such motives may have in some way "hidden" another comorbidity, and the diagnosis was obtained post-mortem through the anatomopathological examination and later confirmed by histopathological examination. Thus, it was considered an incidental finding.
Computed tomography cholangiography allows confirmation of the absence of the gallbladder in dogs. It is considered a non-invasive method that can be combined with laparoscopy, which allows the evaluation of different hepatic lobes if ductal malformations and hypoplasia of the portal vein related to gallbladder agenesis are present (SATO et al., 2016). In patients diagnosed intraoperatively, a meticulous search for possible ectopic sites for the gallbladder, including the intrahepatic ligament, sickle cell ligament, between minor omentum, retroperitoneal, retroduodenal, and retropancreatic areas, is required (BEDI et al., 2013).

Continuous bile excretion in the duodenum and bile salt concentrations are lower in dogs with this condition due to the lack of storage in the gallbladder; however, adaptive changes can occur that increase the daily number of excreta and proportion of bile salts in the duodenum as a compensatory mechanism (POMARE; HEATON, 1973). Treatment recommendations in dogs include drugs that protect against damage caused by secondary hepatopathy and dietary management recommendations to decrease fat intake if necessary (KELLY; MORENO-AGUADO; LAMB, 2019).

Preventing this pathology, avoiding inbreeding, and not using reproducers diagnosed with this disease are important, as this is a congenital disease. The factors associated with this condition are not clearly elucidated, but it is known that gallbladder agenesis is related to abnormal development during embryogenesis and may be correlated with other structural abnormalities during organogenesis (TURKEL; SWANSON; CHANDRASOMA, 1983). In this case report, no kinship data of the patient were found.

\section{CONCLUSIONS}

Dogs with gallbladder agenesis show clinical signs and similar anatomopathological findings with hepatobiliary lesions, such as cholestasis, cholangiohepatitis, and, in severe cases, hepatic encephalopathy, which are necessary to differentiate it from other diseases that affect the hepatobiliary system, such as cholelithiasis and chronic hepatitis. The clinicopathological and histological characterization of gallbladder agenesis is essential for the clinic. Although it is a rare condition, it is valid to consider the possibility of gallbladder agenesis in cases of non-detection in ultrasonography or hepatobiliary symptoms. When there is suspicion, definitive diagnosis and monitoring should be performed due to the risk of progression to severe liver dysfunction.

\section{REFERENCES}

AUSTIN, B.; MICHAEL TILLSON, D.; KUHNT, L. A.. Gallbladder Agenesis in a Maltese Dog. Journal of the American Animal Hospital Association, v. 42, n. 4, p. 308-311, 2006.
BEDI, N.; BOND-SMITH, G.; KUMAR, S.; HUTCHINS, R. Gallbladder agenesis with choledochal cyst - a rare association: A case report and review of possiblegenetic orembryological links. BMJCase Reports, 2013. 
CARVALHO, A. C.; SANTOS COSTA, C.; CORREIA, P.; MAGALHAES, J.; BRITO, D.; MARTINS, M.C.; LONGRAS, C.; SANTOS, T.; CASTRO, V.; OLIVEIRA, J. Gallbladder Agenesis: A Case Report of an intraoperative diagnosis. Revista Portuguesa decirurgia [online], n.43, p. 29-32, 2017.

CHERRONE, K. L.; DEWEY, C. W.; COATES, J. R.; BERGMAN, R. L. A retrospective comparison of cervical intervertebral disk disease in nonchondrodystrophic large dogs versus small dogs. Journal of the American Animal Hospital Association. Vol. 40(4), p. 316-320.

GOFF, J.P. Secretory functions of the gastrointestinal tract. In: Dukes' Physiology of Domestic Animals, 13 ed. Ed Wiley-Blackwell. p. 484, 2015.

JOHNSTON, D. E. Special considerations in interpreting liver function tests. American Family Physician, v. 59, n.8, p.2223-2230, 1999.

KELLY, D.; MORENO-AGUADO, B.; LAMB, V. Gallbladder Agenesis in a Dog: Clinicopathological, Histopathology, and Computed Tomography Findings. Journal of the American Animal Hospital, v. 55, п. 6, e556-02, 2019.

LIPTAK, J. M.; SWINNEY, G. R.; ROTHWELL, T.L.; HUNT, G.B.Aplasia of the gallbladder in a dog. Journal of Small Animal Practice, v.4l, ก. (4):175-177, 2000.

NAIGAMWALLA, D. Z., WEBB, J. A., \& GIGER, U. Iron deficiency anemia. The Canadian veterinary journal = La revue veterinaire canadienne, v.53(3), p. 250-256, 2012.
NELSON, R. W., COUTO, C.G. Manifestações clínicas da doença hepatobiliar. In: Medicina Interna de Pequenos Animais. 5. ed., Elsevier Saunders, Rio de Janeiro, Capítulo 35, p. 1517-1525, 2015.

POMARE, E.W. and HEATON, K.W. The effect of cholecystectomy on bile salt metabolism. Gut, v.14(10), p. $753-762,1973$.

RAMALHO, F. P.; FORMENTON, M. R.; ISOLA, J. G. M. P.; JOAQUIM, J. F. G.; Tratamento de doença de disco intervertebral em cão com fisioterapia e reabilitação veterinária - relato de caso. Journal of Continuing Education in Animal Science of CRMV-SP. São Paulo: Conselho Regional de Medicina Veterinária, v. 13, n. 1, p. 10 - 17, 2015.

SATO, K.; SAKAI, M.; HAYAKAWA, S.; SAKAMOTO, Y.; KAGAWA, Y.; KUTARA, K.; TESHIMA, K.; ASANO, K.; WATARI, T. Gallbladder Agenesis in 17 Dogs: 2006-2016. Journal of veterinary internal medicine, v. 32(1), p. 188-194, 2018.

SCHMILOVITZ-WEISS, H.; GINGOLD-BELFER, R.; GROSSMAN, A. Lowering the upper limit of serum alanine aminotransferase levels may reveal significant liver disease in the elderly. Plos One, v. 14(4):e0212737, 2019.

SINHA, C.K.; DAVENPORT, M. Biliary atresia. Journal of Indian Association of Pediatric Surgeons, v. 13(2), p. 49-56, 2008.

TURKEL, S.; SWANSON, V.; CHANDRASOMA, P. Malformations associated with congenital absence of the gall bladder. Journal of Medical Genetics, v.20, p. 445-449, 1983. 